Research article

\title{
Aquifer mapping based on stratigraphic and geoelectrical data analysis in Bedoyo region, Gunung Kidul Regency, Yogyakarta Special Region
}

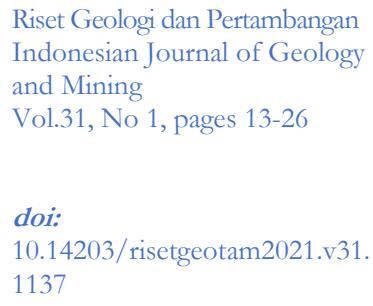

Riset Geologi dan Pertambangan Indonesian Journal of Geology and Mining

Vol.31, No 1, pages 13-26

doi:

10.14203/risetgeotam2021.v31. 1137

Keywords

Bedoyo, aquifer

Schlumberger

geological mapping

Corresponding author

Fatimah

E-mail address:

fatimah@itny.ac.id

Article history

Received 12 Oct 2020

Revised 28 Apr 2021

Accepted 10 May 2021

\author{
Fatimah*, Al Hussein Flowers Rizqi, Waskita Murti \\ Bambang Yudhana \\ Faculty of Mineral Technology, Geological Engineering, Yogyakarta National \\ Institute of Technology (ITNY), Yogyakarta
}

C2021 Pusat Penelitian Geoteknologi - Lembaga Ilmu

Pengetahuan Indonesia

This is an open access article under the CC BY-NC-ND license

(http:// creativecommons.org/1

icenses/by-nc-nd/4.0/).

\begin{abstract}
The research area is a high karst area composed of carbonate rocks, where drought occurred almost every year. This study aimed to determine water availability in aquifer rocks by analyzing the surface geology and subsurface layers (geophysical method). We used the Schlumberger configuration in the geoelectric method at four locations in the study area to determine the resistivity value of the rocks beneath the surface. The results revealed that the site comprises tuff, crystalline limestone, layered limestone /chalky, and gravel to clay deposits. An aquifer was only found in Asem Lulang Village, which has a wedge layer with a thickness of 59 meters and thinned down to 5 meters towards the village of Ngalas Ombo. The value of the resistivity aquifer ranges from 0.18 to $9.18 \mathrm{ohm} . \mathrm{m}$. The existence of that aquifer could indicate that the aquifer is only found in weakly undulated geomorphic units with a height difference of 12.5 meters and a slope of $5.86 \%$.
\end{abstract}

\section{INTRODUCTION}

The water resource is the center of our lives. The supply of water is related to our daily living, either for domestic uses and for other purposes such as agriculture and industry. Water from groundwater sources requires good storage, that is, the aquifer.

Gunung Kidul area has problems of drought and reduced water supply. BPBD Gunung Kidul recorded that 15 of its sub-districts suffer from water shortages. The drought has caused a deficit in both surface water and groundwater. The surface water in the karst area is found in some dry and wet dolinas (Damayanti et al., 2018), while the groundwater resides in the aquifer rocks. The debits of groundwater and spring in Ponjong area are very small and highly dissolved (Afitha et al., 2013). The poor aquifer condition causes a problem in the water supply. The aquifer condition in Gunung Kidul was studied by Uligawati et al. (2020) who found a deep aquifer. 


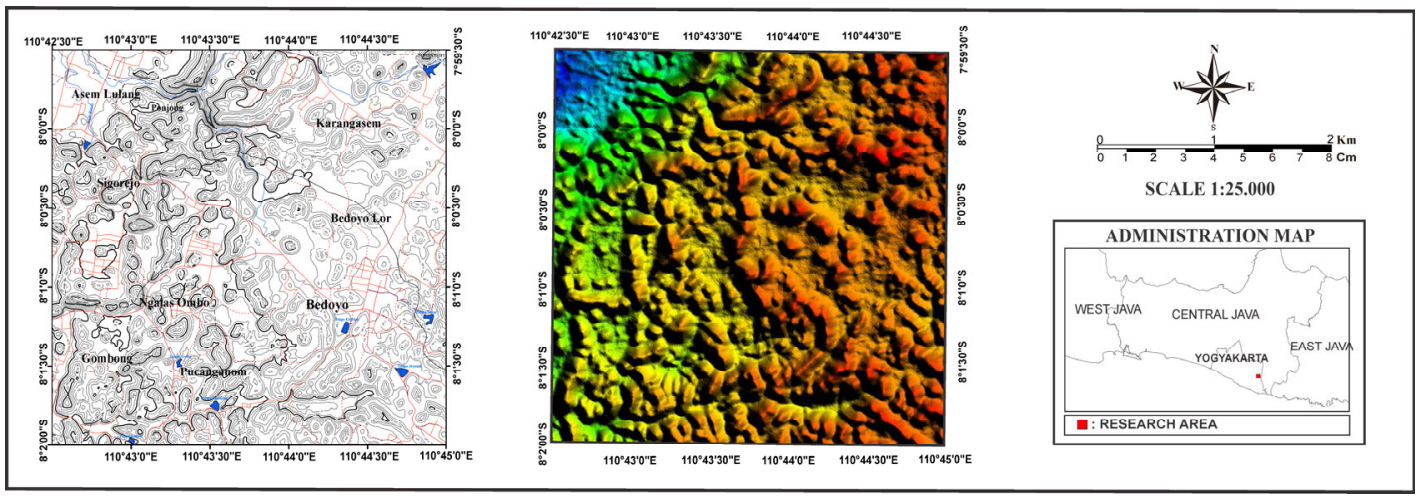

Figure 1. Study location in the Gunung Sewu Karst, Bedoyo Village, Ponjong sub-district, Gunung Kidul.

The study area is located in Bedoyo, Ponjong sub-district, Gunung Kidul regency (Figure 1). The detailed configuration of the aquifer geometry and distribution have not been studied previously. Therefore, it is important to study the aquifer characteristics in-depth. This study observes the water supply and determines the aquifer system by geological mapping and subsurface investigation (geoelectric survey). The rock resistivity data obtained was used to interpret the type of rock, its depth, and its groundwater storage potential. The lithology correlation results in the geometry and distribution of the aquifer system. These results are expected to answer the availability of groundwater resources in the study area.

\section{GEOLOGICAL SETTING}

The study area is part of the regional geomorphology of the Gunung Sewu Karst, part of the Southern Mountain Zone (Darman, 2000). The Ponjong Karst comprises the Wonosari Formation. The Wonosari Formation in Ponjong sub-district consists of Di Kecamatan Ponjong reef limestone, crystalline limestone, reef coral limestone, and clayey limestone (Atmoko et al., 2016)

Previous stratigraphic studies in the Southern Mountain explained that the enrichment process in the terrigenous material and diagenetic influence occur in the Gunung Sewu Karst Zone in Sawahan village, Ponjong (Atmoko et al., 2016, Rizqi \& Yudhana, 2020)).

The diagenetic of Wonosari limestone was interpreted to take place in vadose meteoric, phreatic meteoric, and mixing zones (Setiawan et al., 2018). Diagenesis of the limestone is controlled by the rock facies, which would also influence the porosity.

The water supply for daily human needs is available in the aquifer that is related to rock porosity. The value of rock porosity in Ponjong varies from poor $(5,41 \%)$ to very good $(22,23 \%)$ (Manny et al., 2016).

\section{METHOD}

The literature study was carried out to understand regional geology and the aquifer potential. Geological mapping was carried out to understand the morphology and lithology (stratigraphy). Rock sampling at selected locations was carried out to analyze the petrography of the samples. The classification of carbonate rocks in the field followed the category from (Mount, 1985). The 
petrographic analysis was done following Dunham classification (Dunham, 1962) for clastic carbonate rocks and Embry \& Klovan classification (Embry \& Klovan, 1971) for non-clastic carbonate rock.

Determination of aquifer rocks was made from the geoelectric method (resistivity). The electrode configuration used in this study was the Schlumberger configuration (Figure 2). Four geoelectric measurements were conducted in four villages, and each measurement line was $200 \mathrm{~m}$. Schlumberger method was carried out by maintaining the space between 2 potential electrodes (P1 and P2) as stationary, and the other two alternating current electrodes change gradually (C1 and C2) (Zubaidah \& Kanata, 2008) (Figure 2). Resistivity survey using Schlumberger configuration generally aims to reveal the subsurface geological condition based on the variation of its resistivity as in Table 1.

The specific determination of lithology is based on rock and materials' resistivity values (Telford, 1990) (Table 1). Correlation of lithologic columns was made based on the type and characteristics of lithology from geoelectric survey locations. This correlation reveals the existence, distribution, and geometry of the aquifer system in the study location.

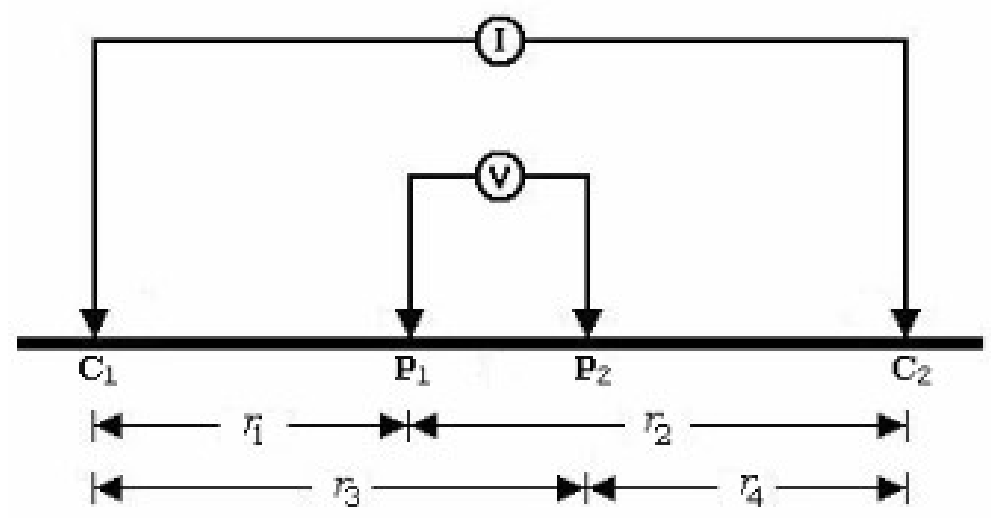

Figure 2. Schlumberger configuration (Zubaidah \& Kanata, 2008).

Table 1. Resistivity values for rock minerals and material (Telford, 1990).

\begin{tabular}{cc}
\hline Material & $\begin{array}{c}\text { Resistivity } \\
\text { (Ohmmeter) }\end{array}$ \\
\hline Surface water & $80-200$ \\
Groundwater & $30-100$ \\
Silt - Clay & $10-200$ \\
Sand & $100-600$ \\
Sand and Gravels & $100-1000$ \\
Mudstone & $20-200$ \\
Sandstone & $50-500$ \\
Tuff & $20-200$ \\
Andesit & $100-2000$ \\
Granite & $1000-10000$ \\
Chert, slate & $200-2000$ \\
\hline
\end{tabular}




\section{RESULTS AND DISCUSSION}

\section{Geology of Study Area}

\section{Geomorphology}

The morphology of the study area is dominated by karst hills (conical hill) and karst valley (Dolina, uvala, and polje). The geomorphological hills consist of weak undulating morphology, denudational, hills- strongly cut karst, and strong undulated unit - karst hills (Rizqi \& Purnomo, 2021). The drainage pattern of the study area is generally multibasinal.

\section{Stratigraphy}

The result of local geological mapping shows that the rock units, from old to young, consist of Semilir Tuff unit, Wonosari crystalline limestone unit, Wonosari laminated limestone unit, and clay-gravel deposits. The description of each rock unit is explained as the following:

\section{Tuff unit}

This unit occupies Telaga Gesing in Pucanganom and Bedoyo Kidul. In Telaga Gesing, this unit is surrounded by karst hill composed of crystalline limestone. The rock outcrop up to the deepest part of the lake is visible during the dry season. The rocks outcrop east and south of the lake are tuff layers. The tuff is greyish brown, laminated, pyroclastic texture, and non-reactive to $\mathrm{HCl}$. The direction of the tuff layer is $\mathrm{N} 30 \mathrm{oE} / 8 \mathrm{o}$. The existence of the tuff is indicated as the result of tectonic uplift and geological structures.

Besides field mapping, petrographic analysis was carried out to rock sample code BDY-SML01. Petrography shows that the rock is composed of hornblende $(0.25 \%)$, clay mineral (16.75\%), feldspar group (7.25\%), and opaque mineral/hematite (2\%), and volcanic glass matrix (73.75\%). Based on the rock composition, the rock is named Vitric Tuff (Schmid, 1981) (Figure 3).

\section{Crystalline Limestone Unit}

This unit consists entirely of crystalline limestone found in Sigorejo, Gombong, and Pucanganom. The megascopic description shows blackish-grey, massive, with dissolving holes (lapies), non-clastic, and the petrography consists of fossil, calcite, micrite, and vugs (Figure 4).

The diagenetic process occurred in some crystalline limestone seen as red to pink colored calcite. This is indicated that the recrystallization of calcite turned into a dolomite mineral.

The petrography of carbonate rocks is shown in detail in Table 2. The rock composition (fossil, calcite, micrite, and vugs) shows that the crystalline limestone is named Packstone (Dunham, 1962) in thin sections BDY 02, BDY 03, and BDY 05. Grainstone (Dunham, 1962) or Rudstone (Embry \& Klovan, 1971) are in BDY 06 thin section. Fossils found in the thin section are small and large foraminifera (Nummulites sp.) (Figure 5). Calcite (Cal) has anhedral - subhedral, vugs, seen as black. 


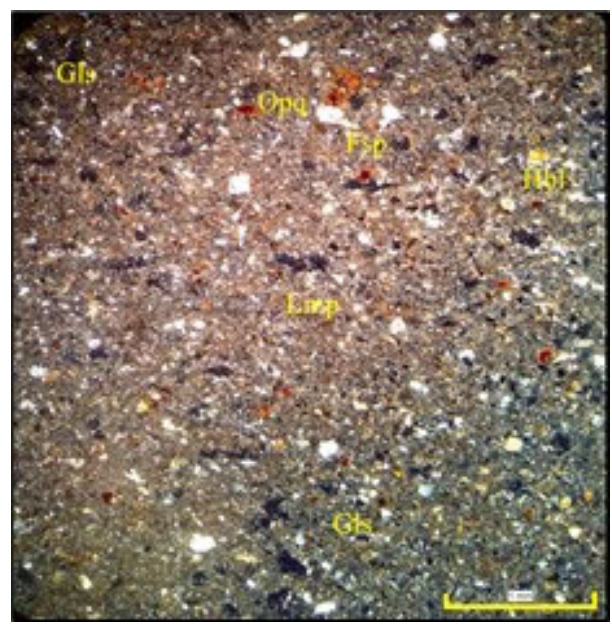

Figure 3. Micrograph XPL Vitric Tuff showing an abundance of glass (Gls), opaque (opq), hornblende (Hbl), and Felspar (Fsp).

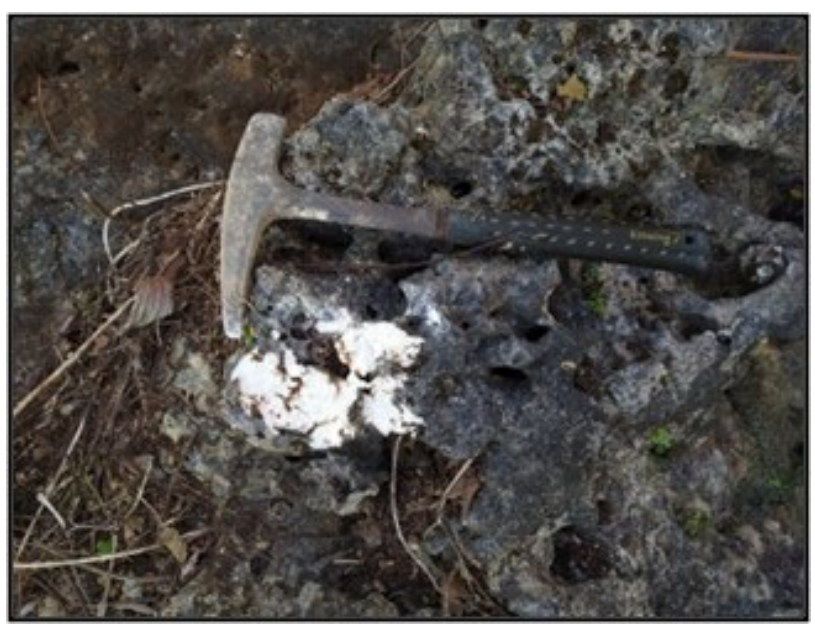

Figure 4. Crystalline limestone in the field showing dissolving hollows (lapies).

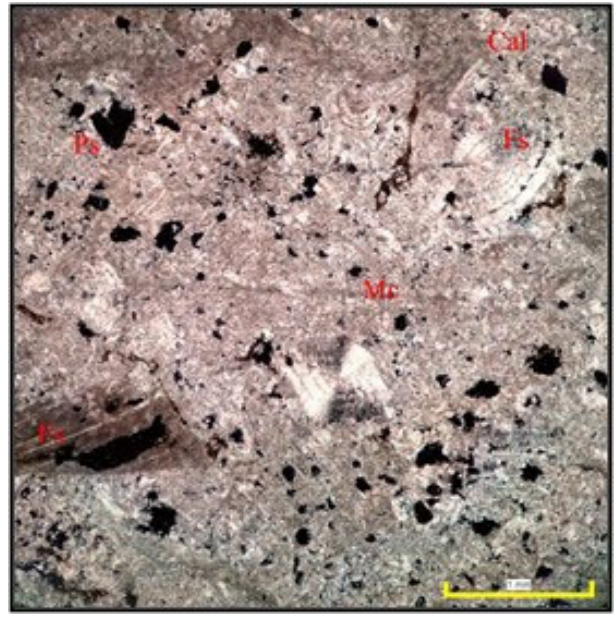

Figure 5. XPL micrograph showing reworked fossil Nummulites sp (Fs), Micrite (Mc), and Calcite (Cal). 


\section{Laminated limestone (Chalky)}

This unit is dominated by laminated limestone, spread over Karangasem and Bedoyo villages. The dissolving holes (lapies) are not common. The megascopic description shows white color, easily ground, sand grain size, with fossil and carbonate minerals (Figure 6).

This laminated limestone found in the field is not too compact and easily ground, therefore resistant to weathering and dissolving. Several sites are showing dolomitization (Maizar dan Hastuti, 2017). This is supported by petrographic analysis showing vugs abundance of 21\% (BDY-01).

Petrography analysis of BDY-01 sample results in fossil (36.5\%), micrite (42.5\%), and vugs (21\%). The rock is classified as Packstone (Dunham, 1962) (Figure 6). The large foraminifera identified is reworked from paleonummulites sp. The vugs are seen as dark black (Figure 7).

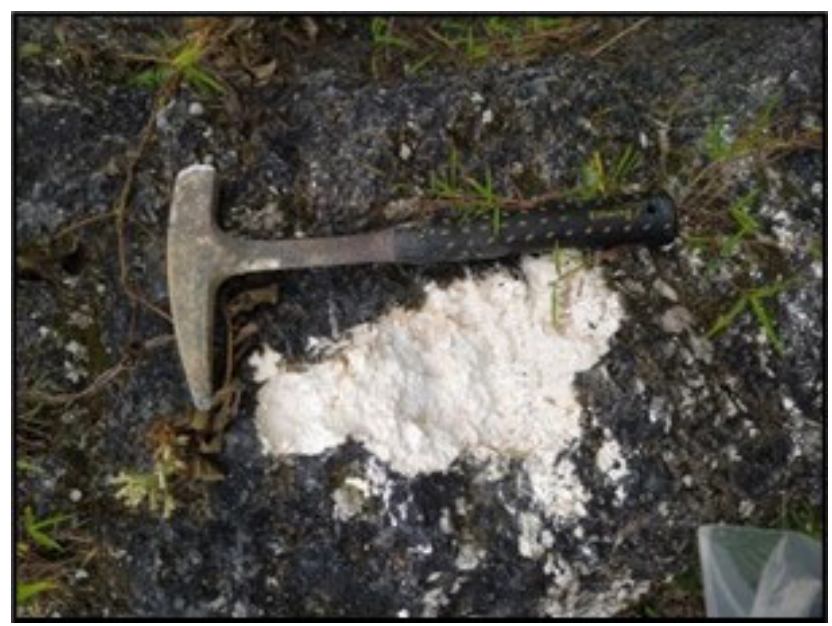

Figure 6. Clastic laminated limestone (clastic), sand grain size, no lapies.

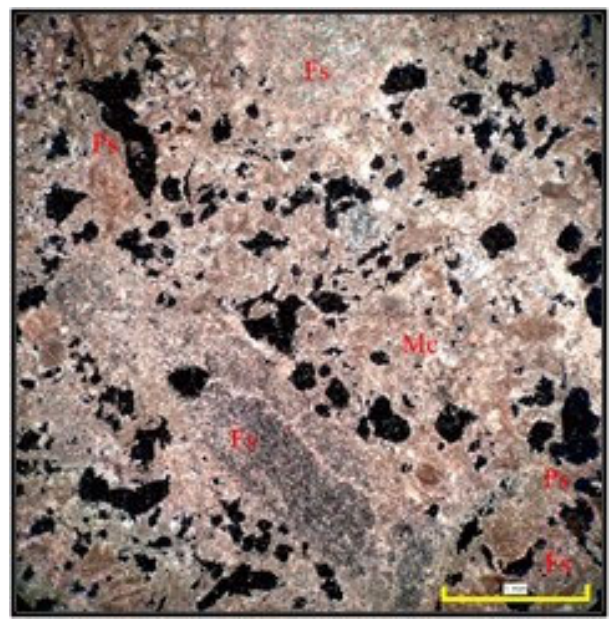

Figure 7. XPL micrograph of Packstone showing the dominance of fossil (Fs), micrite (Mc), and vug (Po). 
Table 2. Composition of carbonate rocks in the study area based on petrography.

\begin{tabular}{|c|c|c|c|c|c|c|c|}
\hline \multirow{2}{*}{ No } & \multirow{2}{*}{ Code } & \multirow{2}{*}{ Type of limestone } & \multicolumn{4}{|c|}{ Composition (\%) } & \multirow{2}{*}{ Name } \\
\hline & & & Fossil & Calcite & Micrite & Vugs & \\
\hline 1 & BDY01 & Chalky (clastic) & 36.5 & - & 42.5 & 21 & Packestone \\
\hline 2 & BDY02 & $\begin{array}{l}\text { Crystalline } \\
\text { (non-clastic) }\end{array}$ & 51.75 & 8.75 & 34.25 & 5.25 & $\begin{array}{l}\text { Packestone / } \\
\text { Floatstone }\end{array}$ \\
\hline 3 & BDY03 & $\begin{array}{l}\text { Crystalline } \\
\text { (non-clastic) }\end{array}$ & 34 & 6.25 & 50.55 & 09.25 & Packestone \\
\hline 4 & BDY05 & $\begin{array}{l}\text { Crystalline } \\
\text { (non-clastic) }\end{array}$ & 41.25 & 20.5 & 37.75 & 0.5 & Packestone \\
\hline 5 & BDY06 & $\begin{array}{l}\text { Crystalline } \\
\text { (non-clastic) }\end{array}$ & 72.25 & 5.75 & 6.5 & 15.5 & $\begin{array}{l}\text { Grainstone / } \\
\text { Rudstone }\end{array}$ \\
\hline
\end{tabular}

\section{Gravel- Clay Unit}

This unit is composed of deposits of loose material from the areas near Bindo River. The deposition of clay to gravel area spread around at the northwest of the study area.

\section{Subsurface mapping}

Geoelectric survey was carried out in four sites at Bedoyo village Dusun Asem Lulang, Dusun Ngalas Ombo, Dusun Bedoyo Lor, and Telaga Mendak. Determination of the rock and aquifer layer was carried out from rock resistivity resulted from the geoelectric survey with Schlumberger configuration.

The processing results will produce four subsurface rock columns generated from the Progress software (Figure 8). The distance between locations varies approximately 1 - $2 \mathrm{~km}$, with the length of the electrode stretch used is 200 meters each and has a relatively north-south stretch direction (Figure 9). Determination of subsurface lithology is carried out by correlating local geological outcrop data with previous studies and regional geology (Surono et al., 1992).

The resistivity rock value indicating the presence of an aquifer layer is in the low-value range (Telford, 1991). The aquifers in the study area are divided into two, namely shallow aquifers and deep aquifers. According to Sapari (2006), shallow aquifers are limited only to aquifers that are up to 50 meters deep, and deep aquifers are aquifers that are more than 50 meters deep.

the village area, geoelectric data collection of four points (trajectories) is considered sufficient to determine the distribution and correlation of aquifers. The reason for choosing the four locations for geoelectric data collection is because they are data collection locations, including drought areas, subsidence, lakes, and springs. In addition, the existence of geological factors such as differences in morphology and lithology that make up the area on each track is a factor of consideration.

The geoelectric data processing using Progress software resulted in interpreting the subsurface rock column (Figure 8 and 9). The distance between locations varied 1-2 km, each with $200 \mathrm{~m}$ traverses, directed North-South (Figure 10). Subsurface lithology was carried out by correlating the rock outcrop with data from a previous study (Prasetyadi et al., 2011). The resistivity value shows that the aquifer layer exists in the low-value range (Telford, 1990). The aquifer in the study area comprises shallow and deep aquifers. According to (Yuniardi et al., 2019), the shallow aquifer is limited to the depth of $50 \mathrm{~m}$, and the depth aquifer is more than $50 \mathrm{~m}$ deep.

For the scope of the village area, four lines of the geoelectric survey are considered sufficient to represent the distribution and aquifer correlation. 


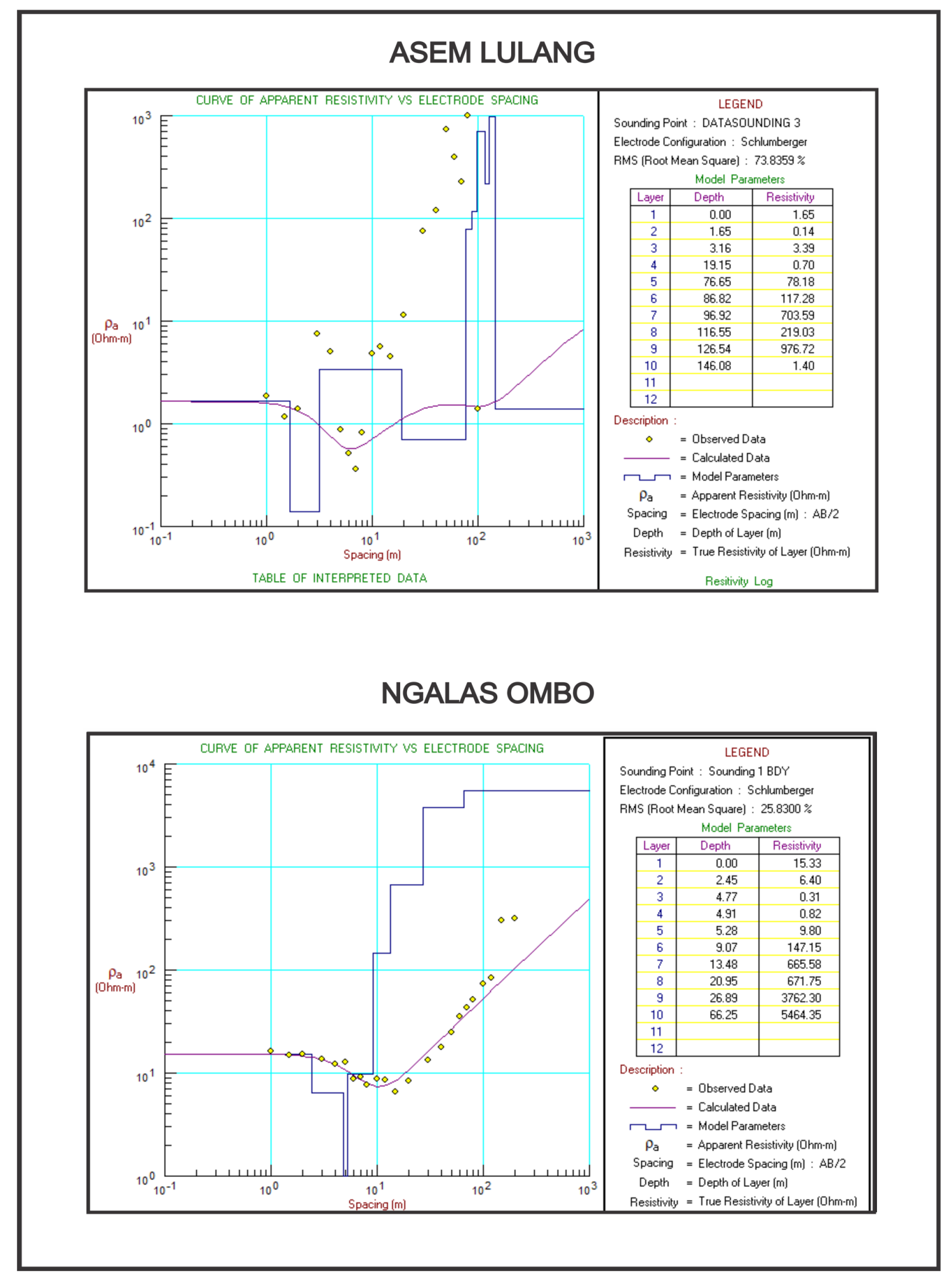

Figure 8. Result of 1-D geoelectric data analysis in Dusun Asem Lulang and Ngalas Ombo using Progress 3.0 software. 


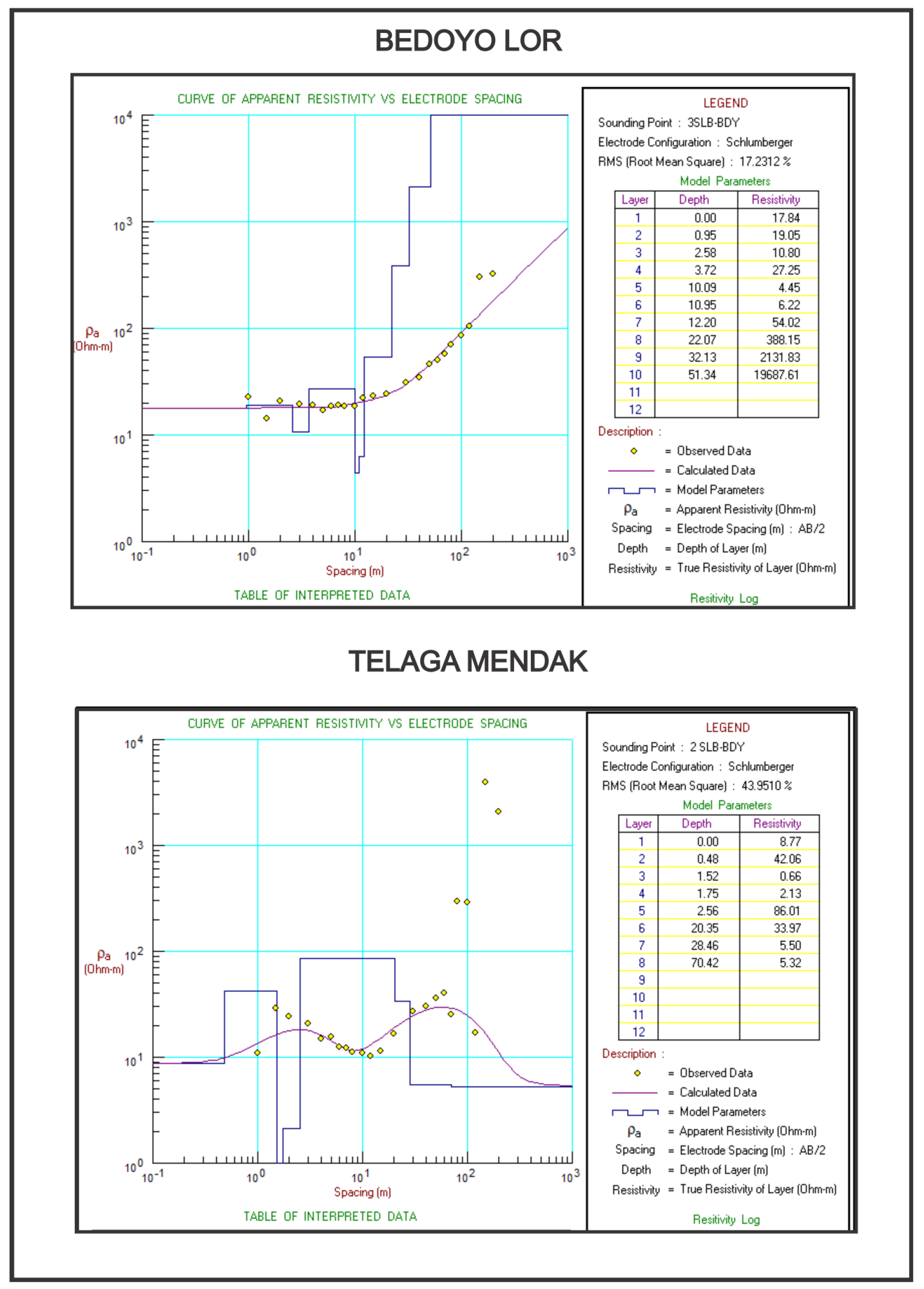

Figure 9. Result of geoelectric 1-D analysis in Asem Lulang dan Ngalas Ombo using software Progress 3.0. 


\section{Dusun Asem Lulang}

The survey was carried out within the weak undulated denudational morphology with a clay-gravel deposit in the surface northwest of the research area.

This location was chosen due to subsidence in the area. Based on the rock resistivity (Telford, 1990), the subsurface lithology is crystalline limestone, calcarenite, and calcilutite (Table 3).

The range of resistivity for sedimentary deposit is within $0.12-4.63 \mathrm{ohm}$.m with a thickness of 15 meters. Below the loose sediment, there is a relatively low resistivity value of 0.18 . This layer is interpreted as an aquifer. Sinkhole subsidence occurrence is possible due to an underground river channel (Rizqi \& Yudhana, 2020a) that can be an aquifer zone (Rizqi \& Yudhana, 2020b). Laminated limestone/calcarenite (chalky) (Boggs, 2006) is interpreted from resistivity values of 124.90 and $129.96 \mathrm{ohm}$ meters at the depths of 74 meters and 90 meters in this location.

Table 3. Interpretation of lithology and aquifer determination in Asem Lulang village.

\begin{tabular}{cccc}
\hline Depth (m) & Thickness (m) & Resistivity $(\boldsymbol{\Omega} \cdot \mathbf{m})$ & Lithology \\
\hline $0-15$ & 15 & $0.12-4.63$ & Unconsolidated sediment \\
$15-74$ & 59 & 0.18 & Aquifer \\
$74-79$ & 5 & 124.90 & Limestone (calcarenite) \\
$79-90$ & 11 & 698.78 & Limestone (calcirudite) \\
$90-105$ & 15 & 129.96 & Limestone (calcarenite) \\
$105-125$ & 20 & 988.12 & Crystalline limestone \\
$125-180$ & 55 & 0.25 & Aquifer (?) \\
\hline
\end{tabular}

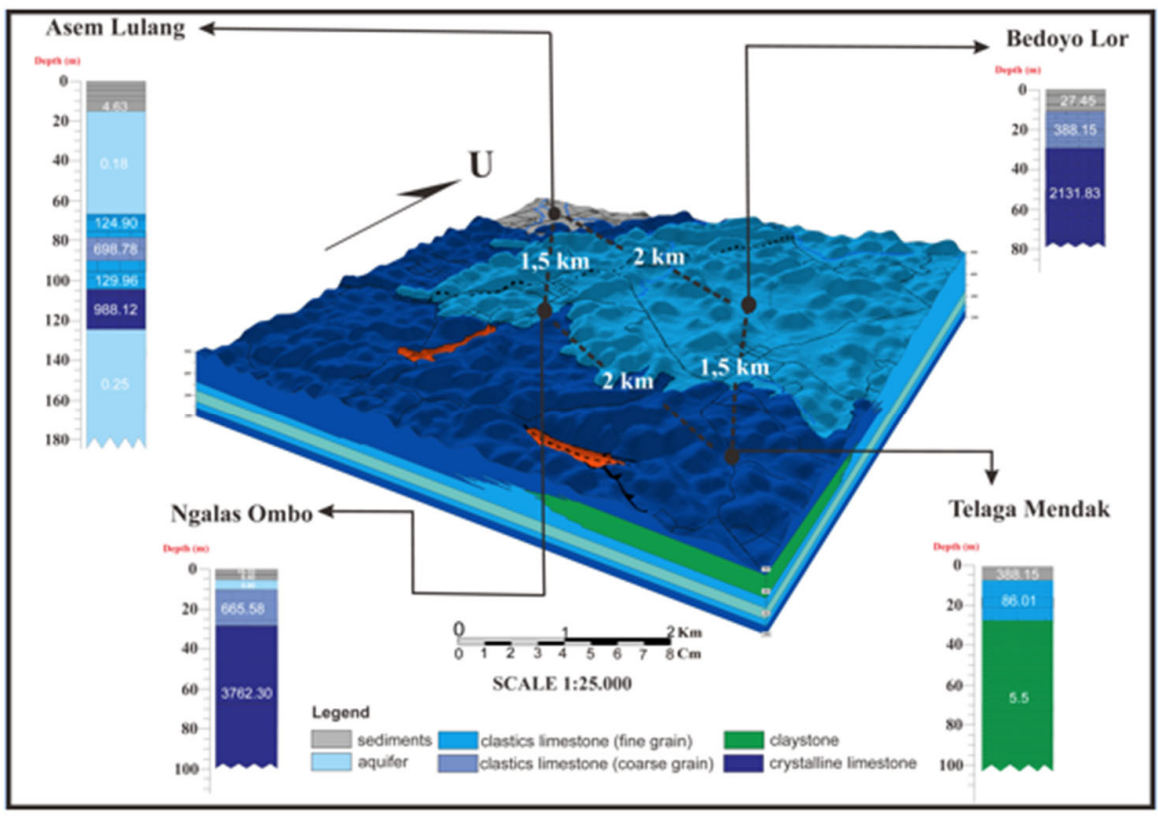

Figure 10. Stratification of rock based on resistivity value. 
Table 4. Interpretation of lithology and aquifer determination in Ngalas Ombo village.

\begin{tabular}{cccc}
\hline Depth (m) & Thickness (m) & Resistivity $(\Omega . m)$ & Lithology \\
\hline $0-10$ & 10 & $6.4-10.33$ & Unconsolidated sediment \\
$10-15$ & 5 & 9.80 & Aquifer \\
$15-30$ & 15 & 665.58 & Limestone (calcirudite) \\
$30-100$ & 70 & 3762.30 & Crystalline limestone \\
\hline
\end{tabular}

Table 5. Interpretation of lithology and aquifer determination in Bedoyo Lor village

\begin{tabular}{cccc}
\hline Depth (m) & Thickness $(\mathbf{m})$ & Resistivity $(\mathbf{\Omega m})$ & Lithology \\
\hline $0-10$ & 10 & 27.49 & Unconsolidated sediment \\
$10-30$ & 20 & 388.15 & Limestone (calcirudite) \\
$30-75$ & 45 & 2131.83 & Crystalline limestone \\
\hline
\end{tabular}

Table 6. Interpretation of lithology and aquifer determination in Bedoyo Kidul village

\begin{tabular}{cccc}
\hline Depth (meter) & Thickness (meter) & Resistivity $(\Omega . m)$ & Lithology \\
\hline $0-10$ & 10 & 388.15 & Unconsolidated sediment \\
$10-30$ & 20 & 86.01 & Limestone (calcarenite) \\
$30-100$ & 70 & 5.5 & Claystone \\
\hline
\end{tabular}

Calcarenite has sand grain size $(1 / 16-2 \mathrm{~mm})$. Calcirudite limestone has a larger grain size than calcarenite (more than $2-4 \mathrm{~mm}$ ), is interpreted to be intercalated with calcarenite with a resistivity value of 698,78 ohm.m. Crystalline limestone is interpreted from a resistivity value of 988.12 ohm.m. The lowest rock strata in Asem Lulang village is construed as an aquifer with a resistivity of $0.25 \mathrm{ohm} . \mathrm{m}$. Aquifers in Asem Lulang are the unconfined aquifer and confined aquifer (Todd \& Mays, 2005).

\section{Dusun Ngalas Ombo}

Geoelectric survey was carried out in strong undulated morphology - karst hill in Ngalas Ombo village with laminated limestone (chalky) lithology. Results show that the lithology in Ngalas Ombo consists of loose deposit, calcarenite limestone, and crystalline limestone (Table 4).

The lithology at the surface up to the depth of $10 \mathrm{~m}$ is the loose sediment. The resistivity value for this layer ranges from $0.12-4.63 \mathrm{ohm} . \mathrm{m}$. The intercalation of $5 \mathrm{~m}$ thick is interpreted as an aquifer. Calcirudite limestone (Boggs, 2006) has a resistivity value of $665.58 \mathrm{ohm} . \mathrm{m}$. Crystalline limestone has a resistivity of $3762.30 \mathrm{ohm} . \mathrm{m}$, interpreted as the basement rock in this location.

\section{Dusun Bedoyo Lor}

Geoelectric data acquisition was carried out in Bedoyo Lor village by considering a borehole well near this location. This location is located in strong undulated geomorphology - karst hills with laminated limestone lithology (chalky). The lithology in Bedoyo Lor consists of loose sediment, calcirudite limestone, and crystalline limestone (Table 5).

Based on Table 4, the resistivity of $27.49 \mathrm{ohm} . \mathrm{m}$ at a depth of $10 \mathrm{~m}$ is interpreted as unconsolidated sediment. The resistivity of $388.15 \mathrm{ohm} . \mathrm{m}$ is interpreted as calcirudite limestone (Boggs, 2006). Crystalline limestone has a resistivity of $2131,83 \mathrm{ohm} . \mathrm{m}$. 


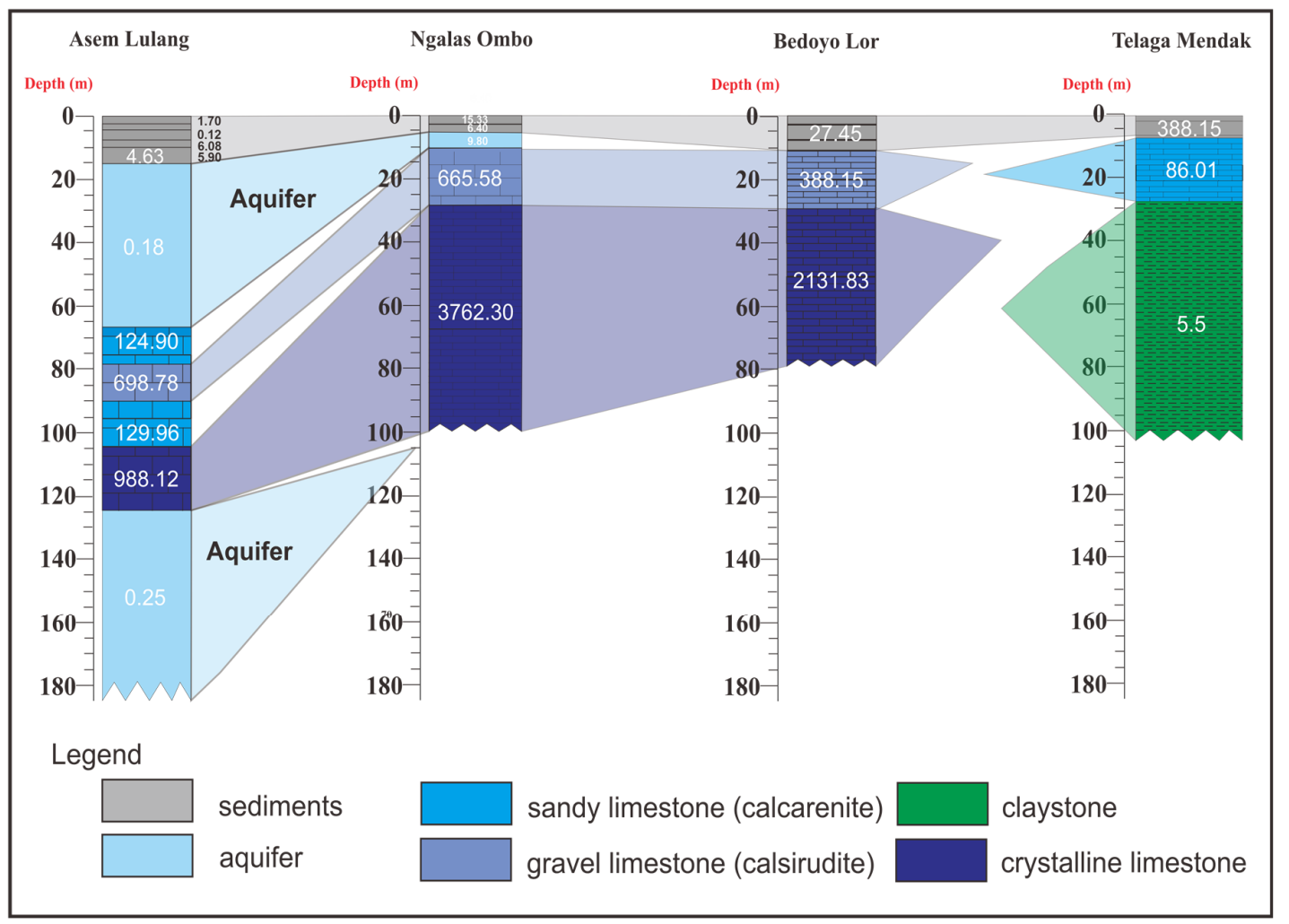

Figure 11. Correlation of lithological column and aquifer based on resistivity value.

\section{Telaga Mendak}

This geoelectric survey took place by the side of Mendak pond (Telaga Mendak) in Bedoyo Kidul village. The pond is dry during the dry season and flooded during the rainy season. The subsurface lithology of the pond consists of unconsolidated sediment, calcarenite limestone, calcarenite limestone, and claystone (Table 6).

Unconsolidated sediment occupies the surface up to the depth of 8-10 m with a resistivity of 388.15 ohm.m. Calcarenite limestone/chalky has a resistivity value of $86.01 \mathrm{ohm} . \mathrm{m}$. The lithology of $70 \mathrm{~m}$ thick is claystone with a resistivity of 5.5 ohm.m.

\section{Subsurface correlation}

Correlation of the distribution of aquifers, the lithology, depths, and locations were carried out to obtain the relationship between aquifer and stratigraphy (Figure 11). The aquifer in Asem Lulang. The aquifer at a depth of $15 \mathrm{~m}$ in Asem Lulang is correlated to the aquifer in Ngalas Ombo at $10 \mathrm{~m}$ deep.

Wedging this aquifer shows that this aquifer layer thins out to the west, with thickness changes from 59 to 5 meters. Considering its dimension and position, the aquifer in Asem Lulang is a perched aquifer \{Formatting Citation\}. This aquifer possibly exists as lenses thinning out to the south. One frequent phenomenon is the seasonal pond in Asem Lulang village that loses water dry during the dry season (Rizqi \& Fatimah, 2020). This aquifer is also below the sedimentary deposit and on top of the harder rocks such as calcarenite limestone.

Aquitard is the strata that can store and permit water flow in a limited amount (Todd \& Mays, 2005). The aquifer is found in weak undulating morphology with surface lithology of soil and sedimentary deposit. Unconfined aquifer (Kruseman \& de Ridder, 1994) in the study area is located 
in Lulang village and Ngalas Ombo at a depth of 15-74 m. An aquifer is also found at a depth of more than $130 \mathrm{~m}$, interpreted as one of the underground river channels (Wiloso \& Ratmi, 2018) (Figure 11).

\section{CONCLUSION}

The aquifer in Bedoyo is found in a weak undulated morphology unit with surface lithology of unconsolidated sediment. The aquifers are located in 2 sites out of 4 investigation sites, in Lulang village and Ngalas Ombo village; they are an unconfined aquifer and perched aquifer at a depth of $15-74 \mathrm{~m}$. The deeper aquifer is also found at a depth of more than $130 \mathrm{~m}$, most likely is one of the river channels.

\section{ACKNOWLEDGMENT}

The authors thank Ristek BRIN (DIKTI) for funding this research within the scheme Penelitian Dosen Pemula (PDP). The authors are also grateful to Institut Teknologi Nasional Yogyakarta (ITNY) for supporting this research.

\section{REFERENCES}

Afitha, A. D., Haryono, E. Wacano, D., 2013. Variabilitas harian bikarbonat ( $\mathrm{HCO}_{3}-$ ) yang terlarut dalam air pada mataair karst di Kecamatan Ponjong, Kabupaten Gunungkidul. In: Sudarmadji (Ed), Ekologi Lingkungan Kawasan Karst Indonesia. Deepublish, Yogyakarta, pp 27-43.

Atmoko, D. D., Titisari, A. D., \& Idrus, A., 2016. Mineralogi dan geokimia batugamping merah Ponjong, Gunungkidul, Daerah Istimewa Yogyakarta, Indonesia. J. Riset Geo. Tam. 26(1), 55-67. https://doi.org/ 10.14203/risetgeotam2016.v26.269

Boggs, S., 2006. Principles of stratigraphy and sedimentology. $4^{\text {th }}$ ed. Pearson Prentice Hall. Upper Saddle River, NJ.

Damayanti, A., Fitri, D., Sari, N., Geografi, D., Matematika, F., \& Alam, I. P., 2018. Karakteristik dan pola persebaran dolina di Kecamatan Ponjong dan Semanu, Kabupaten Gunungkidul. J. Geografi Lingkungan Tropik. 2(2), 50-57.

Darman, H. dan Sidi, F. H. 2000. An outline of the Geology of Indonesia. Indonesian Associaton of Geologist.

Dunham, R. J., 1962. Classification of carbonate rocks according to depositional textures. In: Ham, W. E. (ed), Classification of Carbonate Rocks, AAPG Memoir 1. AAPG (American Association of Petroleum Geologists), Tulsa, Oklahoma, pp. 108-121.

Embry, A. F., Klovan, J. E., 1971. A Late Devonian reef tract on northeastern Banks Island, N.W.T.1. Bulletin of Canadian Petroleum Geology, 19(4), 730-781. https://doi.org/10.35767/gscpgbull.19.4.730.

Kruseman, G. P. \& de Ridder, N. A., 1994. Analysis and evaluation of pumping test data. $2^{\text {nd }}$ ed. International Institute for Land Reclamation and Improvement, Wageningen, Netherlands. 377 pp.

Maizar, N. T. \& Hastuti, M. S., 2017. Geokimia Airtanah di Kawasan Karst Gunungkidul, DIY. Prosiding Sminar Nasional Penelitian dan Pengabdian Masyarakat Universitas Bangka Belitung, 272-277. https://doi.org/ 10.33019/snppm.v1i0.538.

Manny, L., Restu, R., Atmaja, S., Prakasa, D., \& Putra, E., 2016. Groundwater level changes in shallow aquifer of Yogyakarta City, Indonesia: Distribution and Causes. Journal of Applied Geology, 1(2), 89-99. https://doi.org/10.22146/jag.27584

Mount, J., 1985. Mixed siliciclastic and carbonate sediments: a proposed first-order textural and compositional classification. Sedimentology, 32, 435-442. https://doi.org/10.1111/j.1365-3091.1985.tb00522.x

Prasetyadi, C., Sudarno, I., Indranadi, V., \& Surono, 2011. Pola dan genesa struktur geologi Pegunungan Selatan, Provinsi Daerah Istimewa Yogyakarta dan Provinsi Jawa Tengah. Jurnal Geologi dan Sumberdaya Mineral, 21(2), 91-107. https://doi.org/ 10.33332/jgsm.2011.v21.2. 91-107

Rizqi, A. H. F. \& Yudhana, W. M. B., 2020a. Identifikasi keberadaan rongga sebagai pemicu amblesan (sinkhole) berdasarkan data geologi dan geolistrik di Bedoyo, Daerah Ponjong, Kecamatan Kidul, Kabupaten Gunung. J. Mineral, Energi dan Lingkungan 4(2), 32-45. https://doi.org/ 10.31315/jmel.v4i2.3446

Rizqi, A. H. F. \& Yudhana, W. M. B., 2020b. Penyelidikan geolistrik menggunakan konfigurasi Schlumberger terhadap potensi amblesan Daerah Ponjong, Gunung Kidul. Kurvatek, 5(2), 31-40. https://doi.org/10.33579/krvtk.v5i2.1769.

Rizqi, A. H. F. \& Fatimah, 2020. Penentuan batuan alas dan penyekat berdasarkan metode geolistrik konfigurasi dipole-dipole 
pada Telaga Gesing, Gunung Kidul. Prosiding Seminar Nasional ReTII ke-15, Institut Teknologi Nasional Yogyakarta, pp. 247-254.

Rizqi, A. H. F. \& Purnomo, H. T., 2021. Correlation of lithofacies and depositional environment using Markov chain analysis in Sambipitu formation at Ngalang River, Gunungkidul, Yogyakarta, Indonesia. Sustinere J. Env and Sustain. 5(1), 49-63.

Schmid, R., 1981. Descriptive nomenclature and classification of pyroclastic deposits and fragments. Recommendations of the IUGS Subcommission on the Systematics of Igneous Rocks. Geologische Rundschau, 70(2), 794-799. https://doi.org/ 10.1007/BF01822152

Setiawan, T., Isnaini, S., Asghaf, N., Effendi, I., 2018. Sistem imbuhan air tanah daerah karst Wonosari - Baron, Kabupaten Gunungkidul, Daerah Istimewa Yogyakarta berdasarkan analisis isotop 180 dan ${ }^{2} \mathrm{H}$. Jurnal Lingkungan dan Bencana Geologi, 9(3), 143-155. https://doi.org/ 10.34126/jlbg.v9i3.235

Telford, W., 1990. Applied Geophysics. Cambridge University Press, 751 pp.

Todd, D. K. \& Mays L. W., 2005. Groundwater Hydrology (3rd ed.). John Willey \& Sons.

Uligawati, Fatimah, Rizqi, A. H. F. (2020). Identifikasi akuifer dengan metode geolistrik konfigurasi Schlumberger di Daerah Ponjong, Gunung Kidul. Geoda, 1(1), 1-7.

Wiloso, D. A. \& Ratmi, R. 2018. Analisis porositas batugamping sebagai akuifer di Desa Ponjong, Kecamatan Ponjong kabupaten Gunungkidul, Daerah Istimewa Yogyakarta. Jurnal Teknologi. 11, 125-132. https://doi.org/10.3415/jurtek.v11i2.1404.

Yogatama, N. C., Ustiawan, A. B., \& Julias, R. N., 2017. Karakteristik batugamping Formasi Wonosari: Diagenesis dan rock typing. Proceeding Seminar Nasional Kebumian ke-10, Universitas Gadjah Mada, 486-504.

Yuniardi, Y., Hendarmawan, H., Abdurrokhim, A., Isnaniawardhani, V., Mohammad, F., Alfadli, M. K., \& Ridwan, P., 2019. Pendugaan akifer airtanah dengan metode geolistrik konfigurasi schlumberger di Lereng Utara Gunungapi Tangkubanparahu. J. Riset Geo. Tam., 29(2), 239-253. DOI: 10.14203/risetgeotam2019.v29.1051

Zubaidah, T. dan Kanata, B., 2008. Pemodelan fisika aplikasi metode geolistrik konfigurasi schlumberger untuk investigasi keberadaan air tanah. Teknologi Elektro, 7(1), 20-24. 